\title{
Impact of Farmers' Storage Practices and Storage Hygiene on Grain Losses in Ethiopia
}

\author{
Nezif Abamecha ${ }^{1} \quad$ Kumela Dibaba $^{1} \quad$ Wakuma Bayissa $^{1} \quad$ Debela Hunde $^{1} \quad$ Esayas Mendesil $^{1}$ \\ Menale Kassie ${ }^{2} \quad$ Tadele Tefera $^{2}$ \\ 1.Jimma University College of Agriculture and Veterinary Medicine, P. O. Box 307, Jimma, Ethiopia \\ 2.International Centre of Insect Physiology and Ecology, ILRI Campus, Gurd Shola \\ P.O.Box 5689, Addis Ababa, Ethiopia
}

\begin{abstract}
Cereal and grain legumes play a vital role in food security and as income sources for millions of people in Ethiopia. However, poor storage handling and storage pests lead to high postharvest loss. This study therefore assessed farmers' storage practices and grain storage hygiene status in selected districts of Jimma, West Shoa, and East Wollega zones of southwestern Ethiopia. One district was selected from each zone based on their production potential of selected grain crops such as maize, sorghum, wheat, and fababean. Then, three Peasant Associations (PAs) were randomly selected from each district. For the survey, 377 households (HHs) were interviewed. The present study showed that farmers in the study areas stored their grains in different kinds of traditional structures, such as plastered gombisa (14.1\%), unplastered gombisa (25.5\%), gumbi (13.8\%), polypropylene sacks (41.4\%), and Purdue improved crop storage (PICS) bags (5.3\%) and indicated that most farmers used polypropylene sacks followed by unplastered gombisa. On the other hand, most of farmer's grain storage hygiene status was categorised as poor $(50.7 \%)$ or very poor $(33.3 \%)$. The results of this study demonstrate that the farmers use an inefficient storage facility and adopt poor hygiene practices, which predisposes the stored grains to insects and rodent attacks. Thus, there is a need to train farmers in storage hygiene and develop and disseminate efficient grain storage facilities to reduce loss in farmers 'grain stores.
\end{abstract}

Keywords: Faba bean, farmers’ perception, maize, storage pest, sorghum, storage hygiene

DOI: $10.7176 / F S Q M / 93-05$

Publication date: January $31^{\text {st }} 2020$

\section{Introduction}

Cereal crops, such as maize, sorghum, and wheat, and grain legumes play a key role in food and nutritional security in Sub-Saharan Africa (SSA) (Shiferaw et al., 2011; Oluwakemi and Omodele, 2015). A rapid population increase in SSA is leading to increasing demand for cereals and grain legumes. However, crop productivity is not proportional to the increasing demand for major cereal crops. Food insecurity is thereby a challenge in most SSA countries because of low productivity, climate change, and biotic constraints. Postharvest insect pests are one of the main biotic constraints contributing to losses in yield and quality of stored grains in SSA (Tefera, 2012; Abass et al., 2014; Kumar and Kalita, 2017), contributing to high food prices by removing a part of the supply from the market (Tefera et al., 2016).

Zorya et al. (2011) reported estimated losses of postharvest grain valued at US \$1.6 billion/year, equivalent to about $13.56 \%$ of the total value of grain production in Eastern and Southern Africa alone. High amount of losses occurred mainly during grain storage period; for example, FAO (2010) estimated 20-30\% loss of grains, with an estimated monetary value of more than US\$4 billion annually. In their recent review, Kumar and Kalita (2017) reported $50-60 \%$ losses of cereal grains during storage due to technical inefficiency. This suggests the need to reduce postharvest losses to achieve food and nutritional security in SSA.

In Ethiopia, maize, sorghum, and wheat are the main staple food contributors to food security and income for smallholder farmers. These crops have also been the main cereals grown widely in diverse agro-ecologies of the country. Recent FAOSTAT (2017) data showed that, in 2016, about 7.8 M tonnes of maize were produced on $2,135,572$ ha of land throughout the country. In the same year, 4,752,096 $\mathrm{M}$ tonnes of sorghum was grown in $1,881,917$ ha. However, like most SSA countries, poor postharvest management leads to $20-30 \%$ loss of grain (Tefera, 2016). Earlier studies conducted in different parts of Ethiopia demonstrated significant postharvest losses in smallholder settings throughout the country (e.g., Tadesse et al., 2008; Garbaba et al., 2017). In Ethiopia, like most SSA countries, grain storage systems follow traditional methods; they are poorly constructed with locally available materials and cannot protect stored grains from abiotic and biotic agents such as insect pests and fungal diseases. Furthermore, the poor hygiene of traditional grain storage in Ethiopia favours infestation of insect pests and rodents. This suggests a need to improve the postharvest systems of smallholder farmers and the existing traditional storage structures. Furthermore, it is imperative to use improved grain storage technologies such as metal silos and PICS bags, which showed promising results in reducing postharvest losses in many African countries (Tefera, 2012; Gitonga et al., 2013). Similarly, Tesfaye and Tirivayi (2018) recently observed that improved storage technologies in Ethiopia can enhance the country's food and nutritional security. 
Despite the considerable damaged caused by storage pests, little empirical information is available on current storage practices, pest management methods, or hygiene conditions of grain storage in western Ethiopia. However, understanding farmers' knowledge and perceptions of storage pest management and storage hygiene is very important to developing effective postharvest pest management methods. Therefore, this study was conducted in three zones of southwestern Ethiopia (Jimma, east Wollega, and west Shoa zones) to assess grain storage hygiene, structures, and insect pest management practices adopted by farmers in southwestern Ethiopia.

\section{Material and Methods}

\subsection{Description of the study area}

The study was conducted in three selected zones of southwestern Oromia, Ethiopia: Jimma, East Wollega, and West Shoa zones (Figure 1). Omo Nada in Jimma zone, Bako Tibe in West Shoa, and Gudeya Bila district in East Wollega were purposively selected based on their potential for growing target crops and high postharvest losses (wheat, maize, sorghum, and fababean).

Bako Tibe district is located at $251 \mathrm{~km}$ to west of Addis Ababa in West Shoa Zone. It has an average rain fall of $886.5 \mathrm{~mm}$ and average temperature of $21.2^{\circ} \mathrm{C}$. The area was generally concluded as "WoinaDega" even though some of it was kola (BARC, 2014).

Gudeya Bila woreda is part of the former of Bila Sayo district is situated in East Wollega Zone 272km west of Addis Ababa. It is bounded by Abe dongoro in the north, Gobu Sayo in the south, Horo Guduru Welega zone in the east and Sibu Sire in the west. The annual rainfall of Gudeya Bila districts ranges from maximum $1700 \mathrm{~mm}$ to minimum $1400 \mathrm{~mm}$ and it have a temperature that ranges from $36^{\circ} \mathrm{C}$ to $11{ }^{\circ} \mathrm{C}$. The altitude ranges of the districts are ranges from 1800 to 2400 meters above sea level and the districts have $43.5 \%$ low land, $41.5 \%$ midland and $15 \%$ high land (GBWOARD, 2017).

Omo Nada district is located at $300 \mathrm{~km}$ to south west of Addis Ababa in Jimma Zone. The altitude ranges of the district ranges from 1000 to 3340 meters above sea level. A survey of the land in this district shows that 56.8\% is arable or cultivable, $25.2 \%$ pasture, $6.3 \%$ forest, and the remaining $11.7 \%$ is considered swampy, degraded or otherwise unusable. In addition to maize, sorghum and fababean, Teff and wheat are important cash crops. Coffee is also an important cash crop for this district; between 20 and 50 square kilometers are planted with this crop (Shumeta, 2012).

\subsection{Sources and types of data}

Both primary and secondary sources of data were used for this study. Primary data were collected through a questionnaire survey of grain-storing farmers and through key informant interviews with agricultural experts on similar topics with focus group discussions (FGDs) at zonal and district levels. Furthermore, FGDs were also used to identify the level of stored grain problems for communities, the storage structures in which problems with insects and rodent pests are more serious, forms of grain storage practices (threshed or un-threshed form) more vulnerable to insects and rodent pests, and farmers' management and control methods. Secondary data of study areas on grainstoring farmers (population size) and crop production and productivity were gathered from zonal reports, district agriculture offices, and developmental agents.

\subsection{Sampling procedures}

A three-stage sampling strategy was used to select representative sample grain-storing farmers from the study area. In the first stage, one district was purposively selected from each of the Jimma, East Wollega, and West Shoa zones based on their production. In the second stage, in consultation with district experts, three peasant associations (PAs)from each district were randomly selected as the representative of the districts. In the third stage, a list of farmers was selected from the PAs' numbers. Households were identified using random sampling techniques, and the sample size was determined based on the probability proportion using Yamane's formula (Yamane, 1967).

\[ n=\frac{N}{1+N e^{2}} \]
Where
$\begin{aligned} & \mathrm{N}=\text { the size of population } \\ & \mathrm{n}=\text { the sample size } \\ & \mathrm{e}=\text { error of } 5 \text { percentage points }\end{aligned}$

\subsection{Data collection}

\subsubsection{Questionnaire}

The questionnaire was designed to collect information about farmers' perceptions of problems associated with stored grain insect pests and rodents. Data on grain storage structures, storage form, their perception on losses due to insects and rodents, and management practices were collected through the questionnaire that was administered to grain-storing farmers. 


\subsubsection{Assessment of storage hygiene}

The effect of farmers' storage hygiene status and structure type on insect and rodent pest build-up was assessed through observations using a checklist. Moreover, the storage hygiene condition of the grain stores was qualitatively assessed using a 5-point scale as previously described by Brown et al (2013). Accordingly, suitability for access by rodents to feed on stored grain was categorised as shown in Table 1.

\subsection{Statistical Analysis}

Survey data were summarised, and descriptive statistics were calculated using SPSS (Statistical Package for the Social Sciences) version 20.0. For each question, the percentage of farmers who gave similar responses was calculated for each site. Those who did not respond to certain questions were excluded from the calculations. In instances where a farmer indicated more than one reason for a given question, percentages were calculated for each group of similar responses. Comparative statistical tools such as Chi-square and One-way Analysis of Variance (ANOVA) were conducted to assess any differences in socio-demographic characteristics, storage practices, and management methods for storage pests. Significance level was set at 0.05 , and means were separated by Tukey's Honestly Significant Difference test.

\section{Results}

\subsection{Socio-economic profile}

Most respondents (94.7\%) surveyed in the three districts were male. The age group of 31-40 years had the most farmers $(47.2 \%)$, followed by $41-50$ years $(30 \%)$, which is the middle-aged category. Most of the farmers $(63.7 \%)$ had attended up to grade eight, while $27.1 \%$ had non-formal education (Table 1).

\subsection{Farmers storage practices}

In the study districts, farmers stored their grains in different types of storage structures and containers (Table 3 and Figure 3 ). The type of storage used varied significantly among study districts. Most of the farmers (41.4\%) reported that they stored the grains in polypropylene sacks, except for Omo Nada (52.6\%) and Bako Tibe (40\%), where the majority of farmers stored their grain in traditional granaries, i.e., in un-plastered and plastered gombisa, respectively. Nearly a quarter of the farmers in Bako Tibe and Gudeya Bila stored their grains in traditional granaries indoors. On the other hand, only $11.4 \%$ of farmers in Omo Nada district indicated that they stored their grains in PICS bags (Table 3).

Maize and sorghum were stored in different forms in the surveyed districts. The form of storage varied significantly among districts, with over $80 \%$ of the farmers in Bako Tibe reporting that they stored their maize in shelled form, whereas only about $33 \%$ of farmers in Omo Nada stored in shelled form. On the other hand, most of the farmers (average 37.3\%) stored their sorghum in unshelled form, while the majority (57.7\%) of farmers in Omo Nada stored their sorghum in unshelled form (Table 3). Most farmers (95\%) across the three study districts reported that they dried their grains prior to storage (Table 3).

There were significant differences in the duration of storage of the different grains among study districts. The majority of the farmers stored their grains for less than a year, except respondents in Omo Nada, where most farmers stored maize and sorghum for a year (54.9\% and $42.2 \%$, respectively). In Gudeya Bila, most of the farmers $(41.5 \%)$ stored wheat for a year, whereas $30.5 \%$ stored for more than a year. The majority of farmers $(54.9 \%)$ stored faba bean for six months, while $19.5 \%$ stored it for a year (Figure 2).

The frequency of maintenance of storage structures varied significantly among surveyed districts, with an average of $86.5 \%$ of farmers reporting that they maintained their storage structures once a year, while $13.5 \%$ of the farmers maintained their storage structures every two years (Table 3 ).

\subsection{Management of stored grain pests}

Most respondents (97.9\%) reported that they applied various control measures against insect pests in their storage. Chemical insecticide was the main pest control method mentioned by an average of $96 \%$ of the respondents with significant variations across survey districts. Few farmers mentioned the use of botanicals (insecticidal plants) and other cultural practices for the control of insect pests in their storage. Results of the present study also show significant variations in the source of insecticides among districts, with $60 \%$ of the respondents in Omo Nada reporting agricultural offices, whereas over $98 \%$ of the respondents reported market purchases as the main source of insecticides in each Bako Tibe and Gudeya Bila (Table 4).

\subsection{Hygiene status of storage structures}

Results of assessment of storage hygiene indicate that half of the respondents' grain storage facilities were rated as poor and $33 \%$ were rated as very poor, indicating that they are ideal for rodent infestation. Only less than $10 \%$ of the farmers' grain stores were rated as having average and good storage hygiene (Table 5). Furthermore, results of hygiene assessment and visual observation of grain storage conditions showed that, in all the parameters 
assessed, most farmers' stores had hygiene problems associated with insect pest and rodent infestations (Table 6).

\section{Discussion}

Storage plays an important role in postharvest food supply chains because smallholder farms in Africa usually store their produce for home consumption or as seed until they sell it in local markets (Kumar and Kalita, 2017). Farmers may have different reasons for choosing storage structures. The present study revealed that farmers in the study areas use different types of storage structures and containers to store their grains. Both plastered and unplastered gombisa and gumbi were the most common traditional storage structures used by farmers across the study districts, except in Gudeya Bila, where more than half of the respondents reported polypropylene sacks as the main storage container. Beyene and Ayelew (2015) also reported similar results. The use of bags as the main storage container is reported in different parts of Africa; for example, a recent study conducted in Kenya showed that bag storage was the most common storage method (Mwangi et al., 2017).

Farmers mentioned different reasons for using polypropylene sacks: they are available in local markets, are cost effective, and easily portable. Hodges (2004) also reported similar reasons for using bags. Various studies conducted in Ethiopia showed that smallholder farmers use different traditional storage containers (Tadesse and Basedow, 2004; Haile-Gabriel and Hundie, 2006). There are different forms of traditional storage structures, generally made of locally available materials such as bamboo split, wooden walls, mud, and thatched grass roofs. In different parts of Africa, smallholder farmers store their grains in different traditional granaries (e.g. Kamanula et al., 2011; Midega et al., 2016; Abass, 2017).Nevertheless, traditional storage facilities may predispose the grain to different deterioration agents and cannot guarantee the protection of stored grains for longer durations (Kumar and Kalita, 2017); thus, such grain losses are considered as one main cause of food insecurity for smallholder farmers in developing countries (Manandhar et al., 2018). This suggests a need for improved storage systems such as hermetic silos and PICS bags, which help reduce grain storage losses and maintain grain quality (Manandhar et al., 2018). Tesfaye and Tirivayi (2018) also observed that improved storage technologies in Ethiopia can enhance food and nutritional security in the country.

In the present study, only a small proportion of farmers in Omo Nada district used PICS bag for storing their grain. They mentioned that they started using this hermetic bag very recently and accepted it because it protects grain from insect damage for longer storage periods, reducing postharvest losses of their stored grains. The availability of PICS in required quantities and in markets is still a challenge for the farmers. Gitonga et al. (2015) observed that effectiveness against insects and rodents, security of the stored grain, and the lifespan or durability of the technology are important criteria when choosing grain storage technologies.

The present study also showed that farmers stored maize and sorghum in different forms. Most farmers in Omo Nada use un-plastered gombisa as the common storage structure for sorghum in un-threshed form, which corroborates the earlier study of Mendesil et al. (2007). Similarly, on average, more than half of the respondents stored their maize grain in shelled form, of which the majority of the respondents were in Bako Tibe district, where plastered gombisa is the main storage structure. On the other hand, most of the respondents in Omo Nada, where un-plastered gombisa is the main storage structure, stored their maize in unshelled form. The results of this study are in line with an earlier report by Tadesse et al. (2008), who stated that the form of stored maize determines the method and type of storage containers used. Farmers in the study areas gave several reasons for storing grains in various forms. They also claimed that shelled grains were more susceptible to pest attack, especially in polypropylene sacks. As a result, farmers must carefully manage and treat their grain with chemicals prior to storage to control insect pests. Those who stored their grains shelled said they were easier to store and use when the need arises. They also found it easy to manage or mix chemicals during storage.

Most of the farmers in the study area store their grain for up to one year, depending on their circumstances and grain type. The survey revealed that most of the farmers in the study area do not store grain for more than one year. The findings also indicate that the majority of the farmers store their grain from six months to one year (Fig. 2). This was mostly due to low yield, poor storage structures, and management as well as the situation of the farmers. The result of the current study is in line with the finding of Beyene and Ayelew (2015), who stated that the majority of the farmers in Ethiopia stored grain produce for a period of four months to one year, while a small proportion of the farmers stored it for less than four months or for longer than one year.

In order to cope with the damaged caused by insect pests in their grain stores, farmers applied different insect control methods, with insecticides being the most popular practice in the surveyed districts, where an average of $96 \%$ of the respondents apply it and where nearly all of the respondents reported markets as the main source for purchasing insecticides. Only a small proportion of the respondents applied botanicals and other control methods. A study conducted in Tanzania indicated that about $23 \%$ the farmers use botanicals and $20 \%$ use wood ash, while $51 \%$ use insecticide chemicals, considered to be a modern pest control method (Abbass et al., 2014).During the FGD and field observation, farmers and experts opined that high temperature and poor storage conditions can favour insect infestations, while the presence of spilled grains and trash around grain storage structures facilitates rodent infestation. Losses in storage are accelerated by late preparation of storage structures, late harvesting, poor 
storage facilities, storage bags with very low life spans, and bags easily punctured by rats (Tefera and Adebayo, 2012). It is evident that factors such as high temperature and poor storage hygiene can produce conditions comparatively favourable to insects and thus aggravate infestations. High temperature coupled with high relative humidity and high moisture content of stored produce, together with poor storage hygiene, favour the development of pests and thereby increase storage pest infestations (Gwinner et al., 1996).

\section{Conclusion}

The present study documented different types of traditional storage types, such as gombisa, gumbi, and polypropylene bags; however, such storage facilities are prone to postharvest losses caused by insect pests and rodents. In order to reduce postharvest losses and maintain the quality of stored grain, it is very important to improve postharvest systems in general and storage structures in particular. Improved storage systems that are affordable by smallholder farmers, such as hermetic storages, can be an option. Furthermore, the storage hygiene statuses of most surveyed farmers were poor or very poor, which favours insect pests and rodent infestations (Table 5). Therefore, it is important to implement hygiene measures in and around grain stores in order to hinder insect and rodent infestation, by training farmers through, for example, field days and farmers' field school.

\section{Acknowledgments}

This work was supported by the German Federal Ministry for Economic Cooperation and Development (BMZ) under the RELOAD project. We also gratefully acknowledge the financial support from the UK's Department for International Development (DFID); Swedish International Development Cooperation Agency (Sida); the Swiss Agency for Development and Cooperation (SDC); and the Kenyan Government. The views expressed herein do not necessarily reflect the official opinion of the donors

\section{References}

Adebayo Oluwakemi, A.O. and Omodele, I., 2015. The current status of cereal (maize, rice and sorghum) crops cultivation in Africa: Need for integration of advances in transgenic for sustainable crop production. International Journal of Agricultural Policy and Research 3, 133-145.

Abass, A.B., Ndunguru, G., Mamiro, P., Alenkhe, B., Mlingi, N., Bekunda, M., 2014.Post-harvest food losses in a maize-based farming system of semi-aridsavannah area of Tanzania. J. Stored Prod. Res. 57, 49-57.

Garbaba, C.A., Gurmu, L., Lemessa, F., Hensel, O., 2017. Nutritional deterioration ofstored Zea mays L. along supply chain in southwestern Ethiopia: implication forunseen dietary hunger. J. Stored Prod. Res. 70, 7-17.

Gitonga, Z.M., De Groote, H., Kassie, M. and Tefera, T., 2013.Impact of metal silos on households' maize storage, storage lossesand food security: An application of a propensity score matching. Food Policy 43, 44-55.

Gwinner, J., Harnisch, R., and Muck, O., 1996. Manual on the prevention of postharvest grain losses: post-harvest project, FRG, Germany, 334pp.

Haile-Gabriel, A. and Hundie, B., 2006. Farmers' post-harvest grain management choices under liquidity constraints and impending risks: implications for achieving food security Ethiopia. In: International Association of Agricultural Economists Conference August 12-18, 2006, Gold Coast, Australia. Accessed on 20May 2018. http://ageconsearch.umn.edu/Bitstream /25716/1/pp060120.pdf.

Kumar, D. and Kalita, P., 2017. Reducing postharvest losses during storage of graincrops to strengthen food security in developing countries. Foods 2017, 6, 8; doi:10.3390/foods6010008

Kemeru, D., 2007. Farm Level Survey on Farm Tools and Implements in Jimma and Iluababor Zones. Agricultural mechanization for productivity and sustainable use of the natural resource" Proceedings of the first agricultural mechanization post-harvest and food science research completed research forum, 5-7 June 2007, Addis Ababa, Ethiopia. PP 171-180.

Mendesil, E., Abdeta, C., Tesfaye, A., Shumeta, Z., Jifar, H., 2007. Farmers' perceptionsand management practices of insect pests on stored sorghum in southwestern Ethiopia. Crop Prot. 26, 1817-1825.

Manandhar, A., Milindi, P. and Shah, A., 2018. An Overview of the Post-Harvest Grain Storage Practices of Smallholder Farmers in Developing Countries. Agriculture 2018, 8, 57; doi:10.3390/agriculture8040057

Midega, C.A.O., Murage, A.W., Pittchar, J.O., Khan, Z.R., 2016. Managing storage pests of maize: Farmers' knowledge, perceptions and practices in western Kenya. Crop Protection 90, 142-149.

Shiferaw, B., Boddupalli, M. P., Hellin, J., and Bänziger, M., 2011.Crops that feed the world 6. Past successes and future challenges to the role played by maize in global food security. Food Security 3, 307-327.

Tadesse, A.,Ayalew, A., Getu,E. and Tefera, T., 2008.Review of Research on Post-Harvest Pests. In: Increasing Crop Production through Improved Plant Protection - Volume I. Tadesse, A. (ed.). Plant Protection Society of Ethiopia (PPSE), 19-22 December 2006. Addis Ababa, Ethiopia. PPSE and EIAR, Addis Ababa, Ethiopia. Pp 475-562.

Tadesse, A., Basedow, T., 2004.A survey of insect pest problems and stored productprotection in stored maize in Ethiopia in the year 2000. J. Plant Dis. Prot. 111, 257-265. 
Tapondjou, A., Bouda, H., Fontem, D., Zapfack, L., Lontsi, D., Sondengam, BL., 2000. Local plants used for traditional stored product protection in the Menoua division of the Western Highlands of Cameroon, IOBC Bulletin, pp. 73-77.

Tefera, T., 2012.Postharvest losses in African maize in the face of increasing food shortage. Food Sec. 4, $267-277$.

Tefera, T., and Adebayo, A., 2012.Improved postharvest technologies for promoting food storage, processing, and household nutrition in Tanzania.PP.1-20. International Institute of Tropical Agriculture.

Tefera, T., Kanampiu, F., De Groote, H., Hellin, J., Mugo, S., Kimenju, S., Beyene, Y.,Boddupalli, P.M., Shiferaw, B., Banziger, M., 2011. The metal silo: An effectivegrain storage technology for reducing post-harvest insect and pathogen lossesin maize while improving smallholder farmers' food security in developingcountries. Crop Protection 30, 240-245.

Tesfaye, W. and Tirivayi, N., 2018. The impacts of postharvest storage innovations on food security and welfare in Ethiopia. Food Policy 75, 52-67.

Yamane, T., 1967. Statistics, an Introductory Analysis, 2nd Ed., New York: Harper and Row.

Zorya, S., Morgan, N., Rios, L.D. 2011.Missing food: the case of postharvest grain losses in Sub-Saharan Africa.World Bank, Washington DC, USA.

\section{Table1}

Farmers grain store hygiene scale

\begin{tabular}{ll}
\hline Scale & \multicolumn{1}{c}{ Description } \\
\hline 1 & Very poor: conditions ideal for rodents, Cover and harbour plentiful, possibly food \\
2 & and water and little or no disturbance, about as bad as it gets. \\
3 & Poor $:$ conditions slightly less ideal for rodent infestation than category1. \\
4 & $\frac{\text { Fairly good: }: \text { conditions tidy and clean, but could still be improved. }}{\text { Excellent: }}$ conditions providing no opportunities for rodent populations to live. \\
5 & Very tidy, clean, and open. \\
\hline
\end{tabular}

Table 2

Socio-economic characteristics of the respondents in different districts of southwestern Ethiopia

\begin{tabular}{|c|c|c|c|c|c|}
\hline \multirow[b]{2}{*}{ Variables } & \multicolumn{4}{|l|}{ Districts } & \multirow[b]{2}{*}{$x^{2}$} \\
\hline & $\begin{array}{l}\text { Omo Nada } \\
\mathrm{N}=175\end{array}$ & $\begin{array}{l}\text { Bako Tibe } \\
\mathrm{N}=120\end{array}$ & $\begin{array}{l}\text { GudeyaBila } \\
\mathrm{N}=82\end{array}$ & $\begin{array}{l}\text { Mean } \\
\mathrm{N}=377\end{array}$ & \\
\hline \multicolumn{6}{|l|}{ Gender $(\%)$} \\
\hline Male & 95.4 & 94.7 & 95.1 & 94.7 & \multirow[t]{2}{*}{$0.660^{\text {ns }}$} \\
\hline Female & 4.6 & 6.7 & 4.9 & 5.3 & \\
\hline \multicolumn{6}{|l|}{ Age in years } \\
\hline $20-30$ & 3.4 & 10.0 & 24.4 & 10.1 & \multirow[t]{6}{*}{$66.155^{* * *}$} \\
\hline $31-40$ & 59.4 & 30.0 & 46.3 & 47.2 & \\
\hline $41-50$ & 25.1 & 42.5 & 22.0 & 30.0 & \\
\hline $51-60$ & 4.6 & 13.3 & 2.4 & 6.9 & \\
\hline $61-70$ & 3.4 & 4.2 & 4.9 & 4.0 & \\
\hline$>70$ & 4.0 & 0.0 & 0.0 & 1.9 & \\
\hline \multicolumn{6}{|l|}{ Education level (\%) } \\
\hline Non-formal & 36.6 & 18.3 & 19.5 & 27.1 & \multirow[t]{5}{*}{$38.813^{* * *}$} \\
\hline $1-8$ & 60.0 & 61.7 & 74.4 & 63.7 & \\
\hline $9-10$ & 2.3 & 18.3 & 6.1 & 8.2 & \\
\hline $11-12$ & 1.1 & 0.8 & 0.0 & 0.8 & \\
\hline Above grade 12 & 0.0 & 0.8 & 0.0 & 0.3 & \\
\hline
\end{tabular}

Note: Statistically significant at $* \mathrm{P}<0.05, * * \mathrm{P}<0.01, * * * \mathrm{P}<0.001 ; \mathrm{ns}=$ not significant. 
Table 3

Grain storage methods, storage forms, drying grains, and frequency of maintenance in different districts in southwestern Ethiopia

\begin{tabular}{|c|c|c|c|c|c|}
\hline \multirow[b]{2}{*}{ Variables } & \multicolumn{4}{|l|}{ Districts } & \multirow[b]{2}{*}{$x^{2}$} \\
\hline & $\begin{array}{l}\text { Omo Nada } \\
\mathrm{N}=175\end{array}$ & $\begin{array}{l}\text { Bako Tibe } \\
\mathrm{N}=120\end{array}$ & $\begin{array}{l}\text { GudeyaBila } \\
\mathrm{N}=82\end{array}$ & $\begin{array}{l}\text { Mean } \\
\mathrm{N}=377\end{array}$ & \\
\hline \multicolumn{6}{|l|}{ Storage facility (\%) } \\
\hline Gombisa- un plastered & 52.6 & 0.8 & 3.7 & 25.5 & \multirow[t]{5}{*}{$259.247^{* * *}$} \\
\hline Gombisa-plastered & 0.0 & 40.0 & 6.1 & 14.1 & \\
\hline Gumbi & 0.0 & 23.3 & 29.3 & 13.8 & \\
\hline Polypropylene sack & 36.0 & 35.8 & 61.0 & 41.4 & \\
\hline PICS bag & 11.4 & 0.0 & 0.0 & 5.3 & \\
\hline \multicolumn{6}{|c|}{$\begin{array}{l}\text { Forms of storage (maize \& } \\
\text { sorghum) }(\%)\end{array}$} \\
\hline \multirow[t]{2}{*}{ Shelled } & 32.6 & 81.7 & - & 52.2 & \multirow{6}{*}{$\begin{array}{l}75.162^{* * *} \\
210.376^{* * *}\end{array}$} \\
\hline & 17.7 & 16.7 & - & 17.3 & \\
\hline \multirow[t]{2}{*}{ Unshelled } & 42.9 & 18.3 & - & 32.9 & \\
\hline & 57.7 & 7.5 & - & 37.3 & \\
\hline \multirow[t]{2}{*}{ Both forms } & 24.6 & 0.0 & - & 14.6 & \\
\hline & 24.6 & 0.0 & - & 14.6 & \\
\hline \multicolumn{6}{|c|}{$\begin{array}{l}\text { Drying their grain prior to storage } \\
(\%)\end{array}$} \\
\hline Yes & 96.6 & 91.7 & 97.6 & 95.2 & \multirow[t]{2}{*}{$5.024^{\mathrm{ns}}$} \\
\hline No & 3.4 & 8.3 & 2.4 & 4.8 & \\
\hline \multicolumn{6}{|l|}{$\begin{array}{l}\text { Frequency of maintaining storage } \\
\text { structures }(\%)\end{array}$} \\
\hline Once a year & 87.4 & 100.0 & 64.6 & 86.5 & \multirow[t]{2}{*}{$52.340^{* * * *}$} \\
\hline Every two year & 12.6 & 0.0 & 35.4 & 13.5 & \\
\hline
\end{tabular}

Table 4

Pest management methods in different districts of southwestern Ethiopia

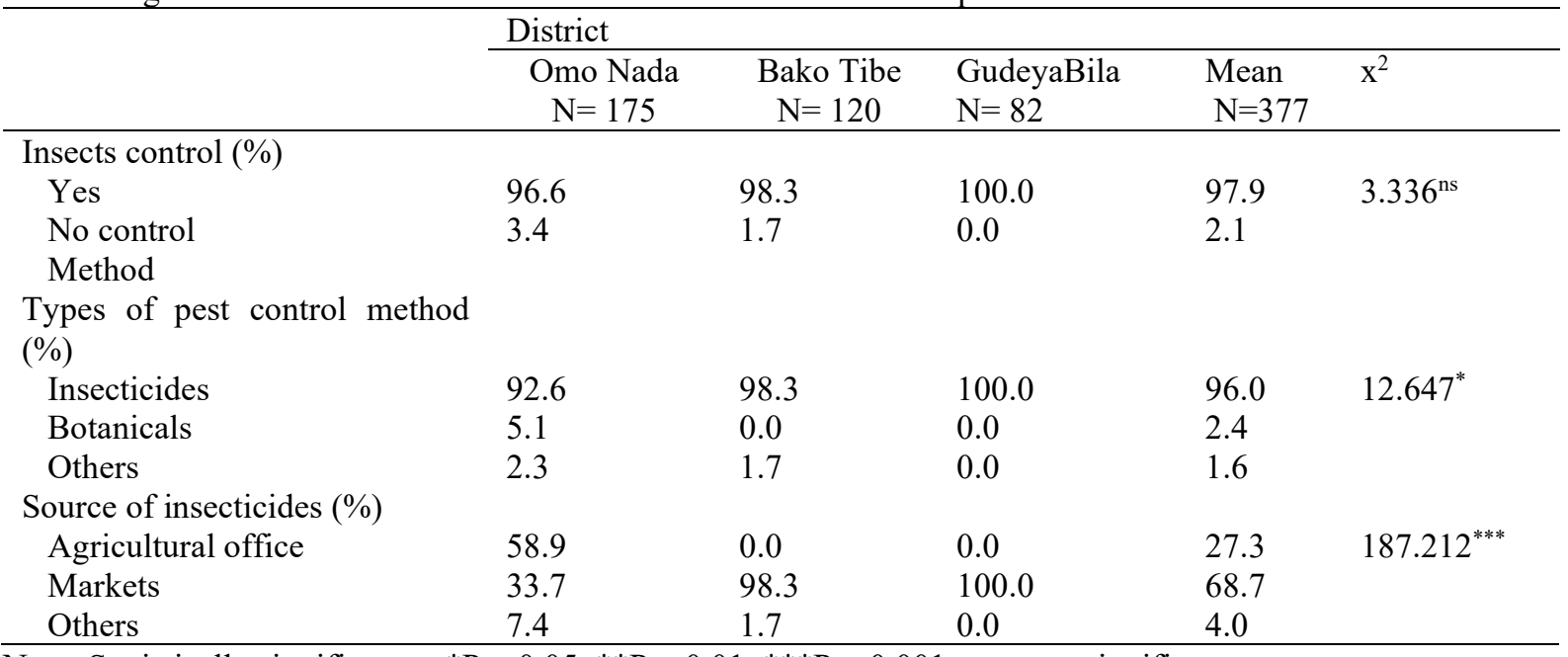

Note: Statistically significant at $* \mathrm{P}<0.05, * * \mathrm{P}<0.01, * * * \mathrm{P}<0.001 ; \mathrm{ns}=$ not significant. 
Table 5

Hygiene status of different types of storage structures in in different districts of southwestern Ethiopia

\begin{tabular}{|c|c|c|c|c|c|c|c|}
\hline \multirow{3}{*}{$\begin{array}{l}\text { Storage } \\
\text { hygiene }\end{array}$} & \multicolumn{2}{|c|}{ Omo nada } & \multicolumn{2}{|c|}{ Bako tibe } & \multicolumn{2}{|c|}{ Gudeyabila } & \multirow{2}{*}{$\begin{array}{l}\text { Mean } \\
\mathrm{N}=75\end{array}$} \\
\hline & $\mathrm{N}=15$ & $\mathrm{~N}=10$ & $\mathrm{~N}=15$ & $\mathrm{~N}=10$ & $\mathrm{~N}=15$ & $\mathrm{~N}=10$ & \\
\hline & $\begin{array}{l}\text { Maize } \\
\text { storage }\end{array}$ & $\begin{array}{l}\text { Sorghum } \\
\text { storage }\end{array}$ & $\begin{array}{l}\text { Maize } \\
\text { storage }\end{array}$ & $\begin{array}{l}\text { Sorghum } \\
\text { storage }\end{array}$ & $\begin{array}{l}\text { Wheat } \\
\text { storage }\end{array}$ & $\begin{array}{l}\text { Faba bean } \\
\text { storage }\end{array}$ & \\
\hline Very poor & 26.7 & 40.0 & 33.5 & 40.0 & 46.7 & 10.0 & 33.3 \\
\hline Poor & 26.7 & 40.0 & 53.3 & 60.0 & 53.3 & 80.0 & 50.7 \\
\hline Average & 13.3 & 20.0 & 13.3 & - & - & 10.0 & 9.3 \\
\hline Fairly good & 33.3 & - & - & - & - & - & 6.7 \\
\hline
\end{tabular}

Note: Refer Table 1 for description of storage hygiene

Table 6

Hygiene assessment and visual observation of grain storage conditions in different districts of southwestern Ethiopia

\begin{tabular}{|c|c|c|c|c|}
\hline \multirow[t]{3}{*}{ Condition of grain storage } & \multicolumn{4}{|l|}{ Districts } \\
\hline & Omo Nada & Bako Tibe & GudeyaBila & Mean \\
\hline & & & & $\mathrm{N}=75$ \\
\hline \multicolumn{5}{|l|}{ Grain store surrounding (\%) } \\
\hline a) Are grain surrounding free of accumulation & 64 & 72 & 32 & 56 \\
\hline of grains, old bags, junk, and trash? No & & & & \\
\hline b) Is the surrounding free of weeds, tall grass, & & & & \\
\hline and bushes? No & 36 & 28 & 68 & 44 \\
\hline \multicolumn{5}{|l|}{ Grain store exterior $(\%)$} \\
\hline a) Is the roof intact? No & 40 & 36 & 44 & 40 \\
\hline b) Are the walls without holes or cracks? No & 40 & 56 & 50 & 49 \\
\hline $\begin{array}{l}\text { c) Are the ventilation, openings protected } \\
\text { against the penetration of insects, rodents, } \\
\text { and birds? No }\end{array}$ & 20 & 8 & 6 & 11 \\
\hline \multicolumn{5}{|l|}{ Grain store interior $(\%)$} \\
\hline $\begin{array}{l}\text { a) Are the walls, the door, and the roof } \\
\text { undamaged? No }\end{array}$ & 28 & 32 & 32 & 31 \\
\hline b) Is the floor and the roof clean? No & 32 & 48 & 52 & 44 \\
\hline $\begin{array}{l}\text { c) Is the floor free of spilled grain, dirt, and } \\
\text { trash? No }\end{array}$ & 20 & 8 & 10 & 13 \\
\hline $\begin{array}{l}\text { d) Is the store free of residues of former } \\
\text { treatments (empty phosphine tubes, phosphine }\end{array}$ & & & & \\
\hline residues, rodent baits, etc ?) No & 20 & 12 & 6 & 13 \\
\hline Presence of pests $(\%)$ & & & & \\
\hline $\begin{array}{l}\text { a) Is the store free of flying insects? No } \\
\text { b) Are the walls and the bags free of crawling }\end{array}$ & 32 & 36 & 32 & 32 \\
\hline insects, larvae, and pupae? No & 32 & 52 & 52 & 45 \\
\hline c) Is the store free of traces of rodents? No & 16 & 8 & 8 & 13 \\
\hline d) Is the store free of traces of birds? No & 20 & 4 & 8 & 12 \\
\hline
\end{tabular}




\section{Figures}

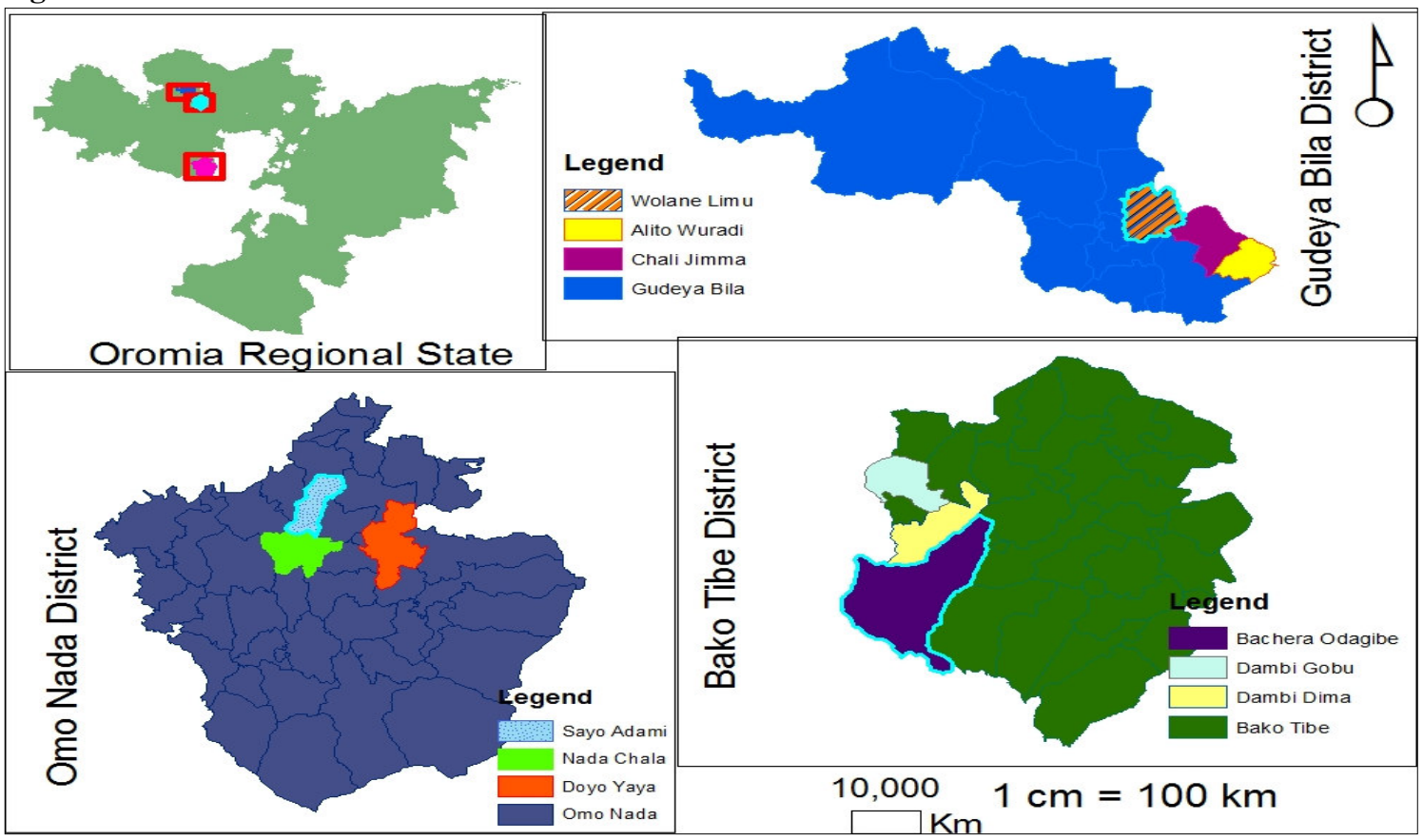

Fig. 1. Map of the study areas in southwestern Ethiopia
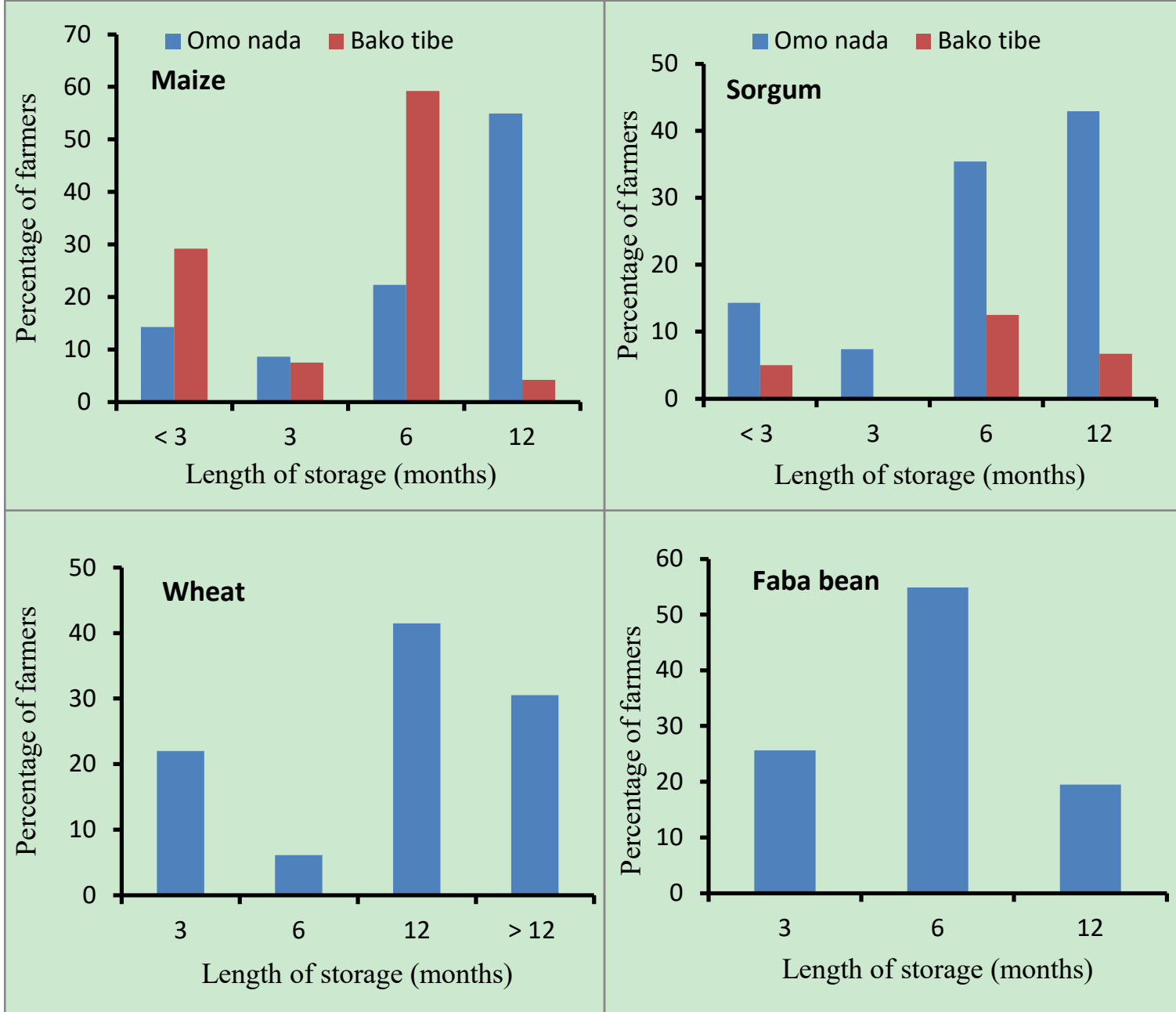

Fig. 2. Duration of storage of maize and sorghum in Omo Nada and Bako Tibe districts, and wheat and faba bean in Gudeya Bila districts in southwestern Ethiopia 

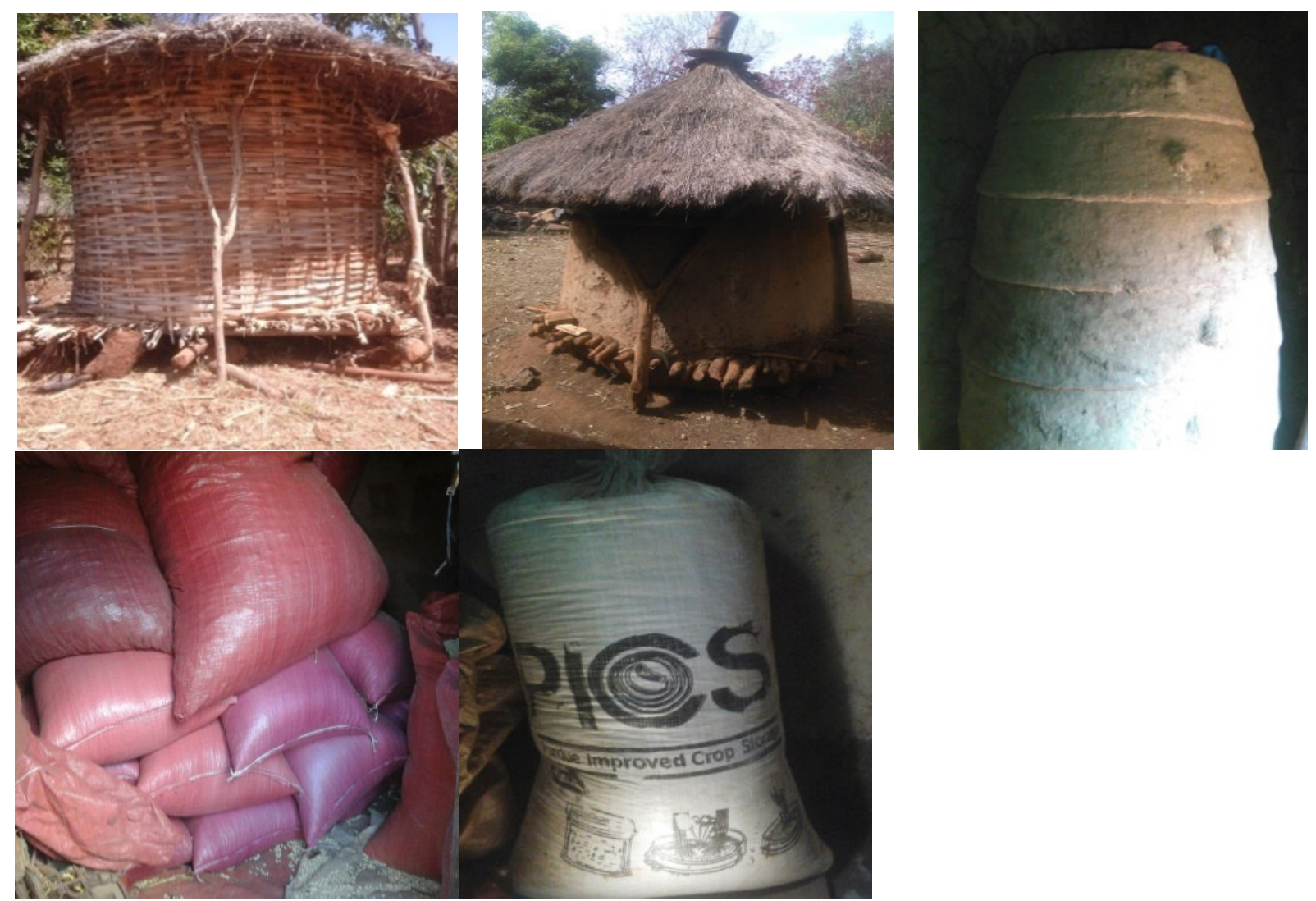

Fig. 3. Grain storage structures in the study districts: un-plastered gombisa (A), plastered gombisa (B), gumbi (C), polypropylene sack (D), and PICS bag (E). 